\title{
Water Environment Characteristics at Taige Canal-Taihu Lake: a Comparative Study on Interaction between Chlorophyll $a$ and Environmental Variables
}

\author{
Liandong Jing ${ }^{1 *}$, Hongyi $\mathrm{Ao}^{2 *}$, Xiaolong Huang ${ }^{2}$, Xiong Xiong², \\ Chenxi $\mathrm{Wu}^{2}$, Jiantong $\mathrm{Liu}^{2 * *}$ \\ ${ }^{1}$ College of Chemistry and Environmental Protection Engineering, Southwest University for Nationalities, \\ 610041 Chengdu, P.R. China \\ ${ }^{2}$ Institute of Hydrobiology, Chinese Academy of Sciences, 430072 Wuhan, P.R. China
}

Received: 12 October 2014

Accepted: 11 December 2014

\begin{abstract}
River-lake connecting system (RLCS) plays an important role in controlling lake eutrophication due to its special geographical position and ecological significance. In addition, the pattern of phytoplankton variation and interaction between chlorophyll $a$ and environmental variables are important for eutrophication management. To understand general water environment characteristics, including relationships between chlorophyll $a$ and environmental variables in the Taige Canal-Taihu Lake system, a comparative study was conducted based on a two-year-long field investigation. This system was divided into a river region and a lake region based on cluster analysis. Investigated field data in the two regions were analyzed separately with principal component analysis (PCA) and stepwise multiple regressions for the relationships among water quality parameters. The spatial variation between the two regions can be found both in patterns of water quality parameters and relationships among them. Multivariate analysis showed that total phosphorous, chlorophyll $a$, and transparency were the main indicators of the spatial variations between the two regions. Relationships among water quality parameters showed that temperature and transparency were the primary environmental factors limiting phytoplankton growth in the river region. However, in the lake region phytoplankton may uptake phosphorus from sediments and its growth was limited by nitrogen during high-temperature seasons. Based on these characteristics, we suggested that reduction of nitrogen input and control of internal phosphorous loading was important for management of eutrophication in the studied area.
\end{abstract}

Keywords: eutrophication, chlorophyll $a$, spatial variation, limiting factor

\section{Introduction}

Lake eutrophication is a worldwide environmental problem caused by excessive emissions of nutrients to water bod-

*These authors contributed equally.

**e-mail: jtliu@ihb.ac.cn ies [1]. These nutrients, including point and nonpoint loads, enter into lakes through inflowing rivers. A major part of these nutrients is settled into lake sediments to become internal loads. Nonpoint pollutants and internal loads are difficult to control or be remove $[2,3]$. The best way to deal with this problem is to prevent nutrients from entering into lakes. 
The river-lake connecting system (RLCS) connects a river and a lake. It is the last barrier for pollutants from a lake basin entering into a lake through an inflow river. Once the last barrier is breached, pollutants disperse into the open lake, where they difficult to manage. RLCS is a complicated system, in which there are many field animals. This system is also interfered with by many human activities, for example aquaculture and shipping. So, for its special geographical position and ecological significance, RLCS has been paid great attention in control of lake eutrophication [4]. Many water pollution control technologies and strategies had been practiced in Gehu Lake-Taige Canal RLCS [4], including pre-reservoirs technology, ecological interception technology, and non-point source pollution control technology. All these countermeasures are proposed based on characteristics of Gehu Lake-Taige Canal RLCS [4]. Regular monitoring is important for theoretical research and engineering practice $[5,6]$. More intensive monitoring data in RLCSs are needed to learn its characteristic and to support lake management. While there has been a substantial amount of research on environmental characteristic in rivers and lakes, there has been little integrated or comparative study for connected RLCSs.

An understanding of the pattern of phytoplankton variation and the relationships between chlorophyll $a$ and environmental variables are important for eutrophication management $[7,8]$. Comparing ecosystems could improve understandings of some general ecosystem principles [9]. Water environment characteristics between a river and a lake are different, including hydrological characteristics, nutrient cycle, and physical and chemical environments. All these differences may contribute to phytoplankton variation and then cause different relationships between chlorophyll $a$ and environmental variables. The objectives of this integrated and comparative field investigation were:

(1) to characterize spatial and temporal variations of physic-chemical variables, as well as chlorophyll $a$ (phytoplankton biomass)

(2) to identify interaction among these variables, especially between chlorophyll $a$ and others, in river and lake regions of the Taige Canal-Taihu Lake system

(3) give some suggestions to lake eutrophication management, especially for the studied region.

\section{Experimental Procedures}

\section{Study Area and Sampling Sites}

The study area $\left(31^{\circ} 30.356^{\prime} \mathrm{N}, 120^{\circ} 07.533^{\prime} \mathrm{E}\right)$, Taige Canal-Taihu Lake system, includes Zhushan Bay of Taihu Lake and the South Taige Canal connected with the Caoqiao River. The Taige Canal and Caoqiao River are two main pollution sources to the upstream portion of Taihu Lake [4]. Zhushan Bay is one of the five most important bays of Taihu receiving waters from the canal. Years ago there were many kinds of large submerged plants in the bay, but they gradually disappeared because of eutrophication [10]. Sedimentation was serious in the bay, thus it had an annual mean depth of less than one meter in the study region. Both Taige and the Caoqiao are seriously polluted by industries, villages, agricultural lands, and aquacultures in their watersheds. Their water quality met grade IV to grade inferior $\mathrm{V}$ requirement of Environmental Quality Standards For Surface Water [11]. After the Caoqiao was connected downstream of Taige Canal, all the polluted water entered into Taihu across the bay. Consequently, Taige became one of the rivers that carry very large external loadings into Taihu [12]. Five sampling sites were selected (Fig. 1): R1, R2, and R3 located in south Taige Canal; and L1 and L2; Zhushan Bay, $300 \mathrm{~m}$ from the nearest estuary. The distance between the neighbor sites was about $500 \mathrm{~m}$.

\section{Sample Analysis}

Surface water was collected monthly from June 2009 to June 2011. Dissolved oxygen (DO, YSI Pro20), pH (YSI 60 ), temperature (Temp, YSI Pro20), and water transparency (Trans, Secchi disk) were measured in situ. Water samples were delivered to laboratory for further analysis. Concentrations of total phosphorus (TP), total nitrogen (TN), chlorophyll $a(\mathrm{Chl} . \mathrm{a})$, permanganate index $\left(\mathrm{COD}_{\mathrm{Mn}}\right)$, ammonium nitrogen $\left(\mathrm{NH}_{3}-\mathrm{N}\right)$, and nitrate $\left(\mathrm{NO}_{3}^{-}-\mathrm{N}\right)$ were measured following Chinese standard methods [13].

\section{Data Analysis}

To characterize the spatial characteristic in the RLCS, cluster analysis and discriminant analysis of annual average variable values of every sampling site were employed with SPSS 16.0. Discriminant function was tested by

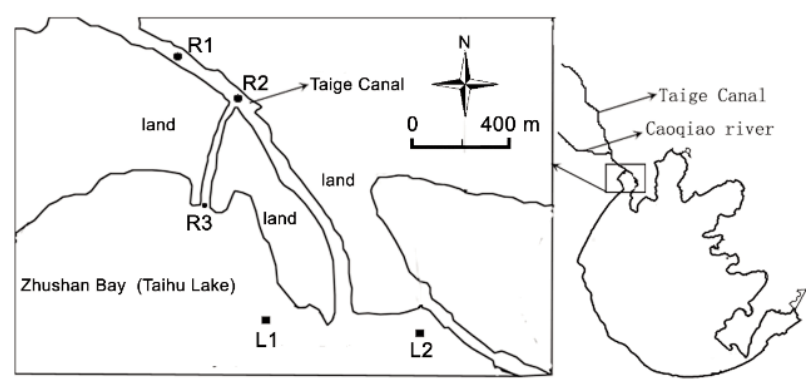

Fig. 1. Sampling sites in the Taige Canal-Taihu Lake system.

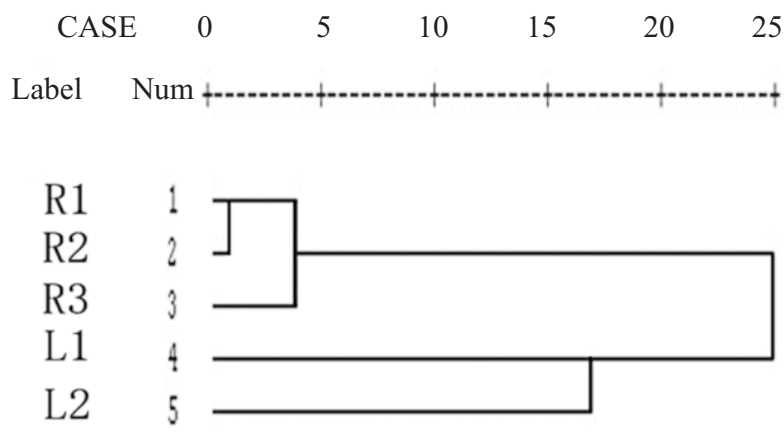

Fig. 2. Dendrogram of cluster analysis of the sampling sites. 
Wilks' Lambda. Seasonal variations of monitored variables were descriptived with the help of time series figures. To identify interaction among monitored variables, principal component analysis (PCA), stepwise multiple regressions between Chl.a (dependent variable), and the first two factors generated from PCA (independent variables), stepwise multiple regressions between Chl.a (dependent variable) and other variables (independent variables), as well as correlate analysis were implemented in river and lake regions, respectively. PCA was a useful method for explaining the variance of a large set of intercorrelated variables with a smaller set of new independent factors [14], being widely used in environmental science [15] and limnology [16-18].

\section{Results and Discussion}

\section{Spatial and Seasonal Variations of Variable Patterns}

Cluster analysis divided the RLCS into two parts (Fig. 2). The first part, including sites R1, R2, and R3 (Fig. 1), belonged to the river region. The second one, including sites L1 and L2 (Fig. 1), belonged to the lake region. The lake region group had longer cluster breaches, which suggested higher variation in the lake region.

The spatial variations of water environment were pronounced between the two regions. Average concentrations of $\mathrm{TP}$ and $\mathrm{NH}_{3}-\mathrm{N}$ were lower in the lake region than those in the
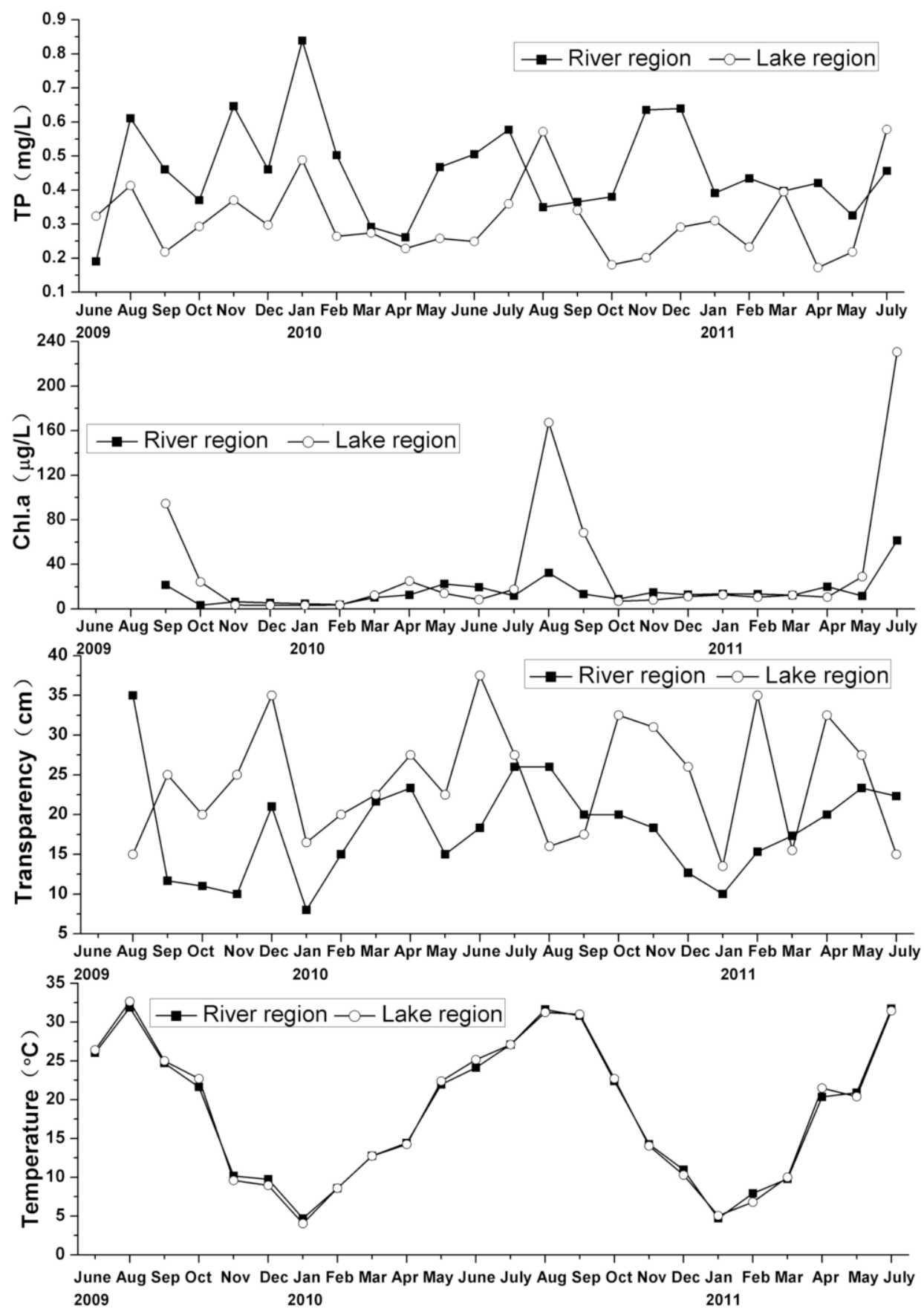

Fig. 3. Temperature and important indexes of variation between the river and lake regions. 
Table 1. Correlation matrix among the variables in the river region (lower left) and the lake region (top right).

\begin{tabular}{|c|c|c|c|c|c|c|c|c|c|c|}
\hline & $\mathrm{TP}$ & $\mathrm{TN}$ & $\mathrm{COD}_{\mathrm{Mn}}$ & $\mathrm{NH}_{3}-\mathrm{N}$ & $\mathrm{NO}_{3}-\mathrm{N}$ & $\mathrm{Chl} . \mathrm{a}$ & $\mathrm{DO}$ & $\mathrm{Trans}$ & $\mathrm{Temp}$ & $\mathrm{pH}$ \\
\hline $\mathrm{TP}$ & 1 & & $\underline{0.595^{* *}}$ & & $-0.432^{* *}$ & $\underline{0.629^{* *}}$ & & $-0.584^{* *}$ & \\
\hline $\mathrm{TN}$ & & 1 & & $0.449^{* *}$ & & & & & $-0.401^{* *}$ & \\
\hline $\mathrm{COD}_{\mathrm{Mn}}$ & & $\underline{0.496^{* *}}$ & 1 & & $\underline{-0.370^{*}}$ & $\underline{0.559^{* *}}$ & & $-0.534^{* *}$ & & $\underline{0.432^{* *}}$ \\
\hline $\mathrm{NH}_{3}-\mathrm{N}$ & & $0.662^{* *}$ & $\underline{0.424^{* *}}$ & 1 & & $-0.383^{*}$ & & & $-0.690^{* *}$ & $-0.354^{*}$ \\
\hline $\mathrm{NO}_{3}-\mathrm{N}$ & $-0.268^{*}$ & $\underline{0.324^{* *}}$ & & $\underline{0.270^{*}}$ & 1 & $-0.450^{* *}$ & & & $-0.456^{* *}$ & $-0.530^{* *}$ \\
\hline $\mathrm{Chl} . \mathrm{a}$ & & & & $-0.389^{* *}$ & $-0.432^{* *}$ & 1 & & $\underline{-0.378^{*}}$ & $0.582^{* *}$ & $\underline{0.345^{*}}$ \\
\hline $\mathrm{DO}$ & & $\underline{0.245^{*}}$ & $\underline{0.295^{*}}$ & $\underline{0.274^{*}}$ & & & 1 & & $-0.589^{* *}$ & \\
\hline $\mathrm{Trans}$ & $-0.242^{*}$ & $\underline{-0.238^{*}}$ & $-0.397^{* *}$ & $\underline{-0.339^{* *}}$ & & $\underline{0.284^{*}}$ & $\underline{-0.297 * *}$ & 1 & & \\
\hline $\mathrm{Temp}$ & & $-0.619^{* *}$ & $\underline{-0.421^{* *}}$ & $-0.743^{* *}$ & $-0.386^{* *}$ & $0.511^{* *}$ & $-0.462^{* *}$ & $\underline{0.585^{* *}}$ & 1 & $0.463^{*}$ \\
\hline $\mathrm{pH}$ & & & & $-0.406^{* *}$ & $-0.318^{* *}$ & & & $\underline{0.389^{* *}}$ & $0.417^{* *}$ & 1 \\
\hline
\end{tabular}

*significant at 0.05 level; **significant at 0.01 level.

Underlined values mean the correlations were different between the river and lake regions.

river region. TP decreased by $33.8 \%$ from $0.468 \mathrm{mg} / \mathrm{L}$ in the river region to $0.310 \mathrm{mg} / \mathrm{L}$ in the lake region. $\mathrm{NH}_{3}-\mathrm{N}$ decreased by $16.0 \%$, from $2.60 \mathrm{mg} / \mathrm{L}$ to $2.18 \mathrm{mg} / \mathrm{L}$. These results suggested that the lake region can dilute and/or decompose pollutants from the river region. For dilution and decomposition, Trans was higher and DO was lower in the lake region than in the river region. In the lake region, Trans increased by $35.2 \%$, from a mean value of $17.8 \mathrm{~cm}$ to $24.1 \mathrm{~cm}$. However, DO content decreased by $15.0 \%$, from $7.76 \mathrm{mg} / \mathrm{L}$ to $6.59 \mathrm{mg} / \mathrm{L}$. what is more, Chl.a in the river region is lower than that in the lake region. There were no obvious changes in terms of average content for other variables.

$$
\begin{gathered}
Y=5.539 \text { TP }+0.026 \text { Chl. } a+0.1 \text { Trans } \\
-0.094 \text { Temp }+1.039 \\
(\lambda=0.578 p<0.001)
\end{gathered}
$$

To select the determinants of the spatial variations between the two regions, a discriminant function (1) was set up by the average variable values of the two regions with SPSS 16.0. In this function, $\mathrm{Y}$ was the discriminant variable. Considering that the spatial variation of Temp was weak (Fig. 3), this function showed that TP, Chl.a, and Trans were the primary determinants of the spatial variation between the two regions. Seasonal changes of these variables in both regions were obvious. Furthermore, these changes had different patterns in different regions.

TP content fluctuated over time and presented different patterns between the two regions (Fig. 3). In the lake region, obvious peaks appeared in both the low-temp seasons (November, December, and January) and the hightemp seasons (July and August). However, TP pattern was irregular in the river region. Although the average concentration of TP in the lake region is lower than the river region, TPs in lake water were close to or even higher than those in river water during high Chl.a seasons. This result suggested that the growth of phytoplankton may cause phosphorus release from lake sediments $[19,20]$. On the other hand, in low temp seasons a lot of phosphorus carried by flora and fauna remains would enter the water body. Therefore, the double TP peaks in one year reflected two main phosphorous sources in the lake region, including external loading from the river and internal loading from the lake sediments [3].

Phytoplankton blooms were reported frequently in Taihu during high temp seasons. The studied region is one of the serious bloom regions [21]. During the investigation (Fig. 3), high Chl.a content was detected in the lake region in September $2009(94.6 \mu \mathrm{g} / \mathrm{L})$, August and September 2010 (167.3, $68.5 \mu \mathrm{g} / \mathrm{L}$ ), and July 2011 (230.7 $\mu \mathrm{g} / \mathrm{L})$. However, in the same months, Chl.a in the river region $(21.5,32.4,13.4,61.5 \mu \mathrm{g} / \mathrm{L}$, respectively) were much lower than in the lake region. This phenomenon resulted because the river water with high velocity and strong light attenuation was not suitable for phytoplankton bloom formation or accumulation [22].

Trans is a combined result of several lake conditions. The patterns of trans could be seen in Fig. 3. In the river region, there were trans peaks in high-temp seasons (July, August) and valleys in low-temp seasons (January). However, there were contrary results for trans in the lake region. It had trans valleys in high-temp seasons when trans peaks were observed in the river region. The lake region also had valleys in low-temp seasons just as the river region had. The trans peaks of the lake region appeared occasionally and randomly, which suggested complex factors, for example randomly wind-caused suspended solids [23], influenced the trans in this region.

Except for the three primary indicators (TP, Chl.a, and trans) of the spatial variations, other investigated parameters only had weak variations between the two regions. The patterns of DO, $\mathrm{pH}$, and temp were similar between the two parts of Taige Canal-Taihu Lake RLCS. The low DO values were found in summer but high values in winter, ranging from $3.57 \mathrm{mg} / \mathrm{L}$ to $11.52 \mathrm{mg} / \mathrm{L}$ and $2.17 \mathrm{mg} / \mathrm{L}$ to 11.26 $\mathrm{mg} / \mathrm{L}$ in river and lake regions, respectively. The $\mathrm{pH}$ was 


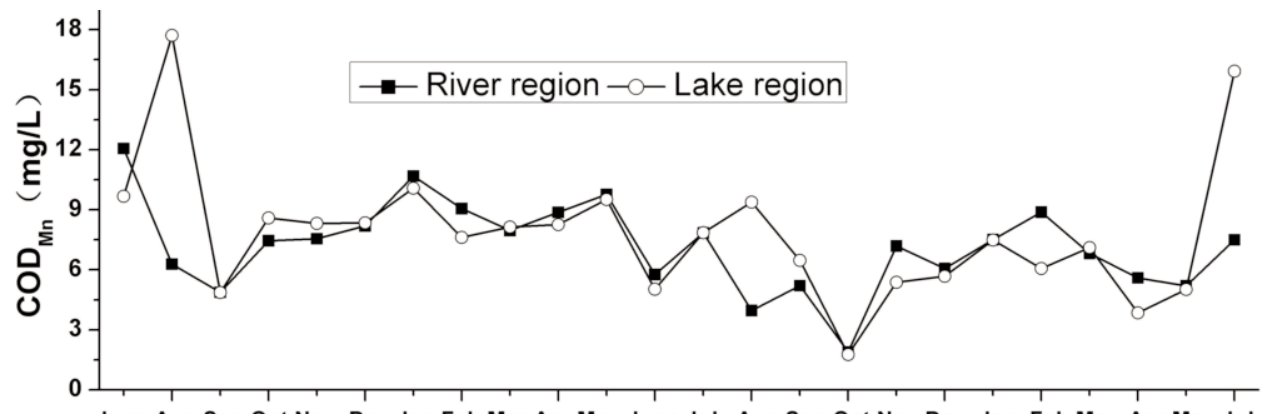

June Aug Sep Oct Nov Dec Jan Feb Mar Apr May June July Aug Sep Oct Nov Dec Jan Feb Mar Apr May July $8 \stackrel{2009}{2}$ 2010 2011
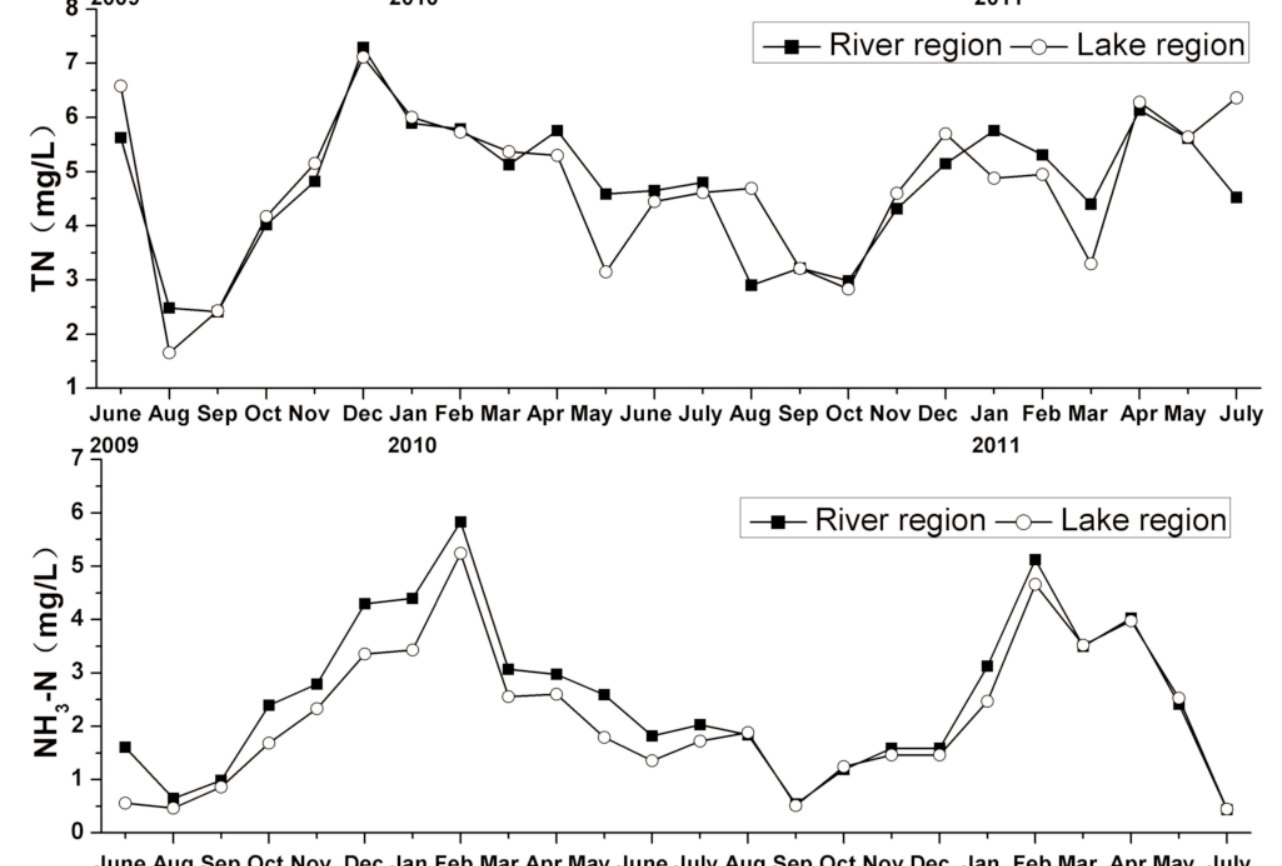
June Aug Sep Oct Nov Dec Jan Feb Mar Apr May June July Aug Sep Oct Nov Dec Jan Feb Mar Apr May July

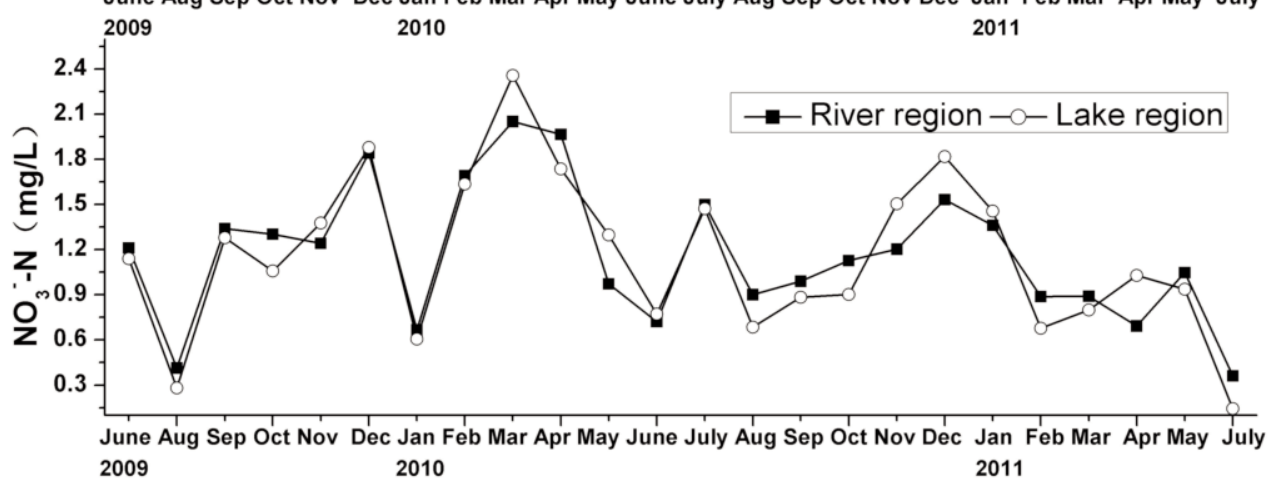

Fig. 4. Concentrations of total nitrogen, ammonium nitrogen, and nitrate in the RLCS.

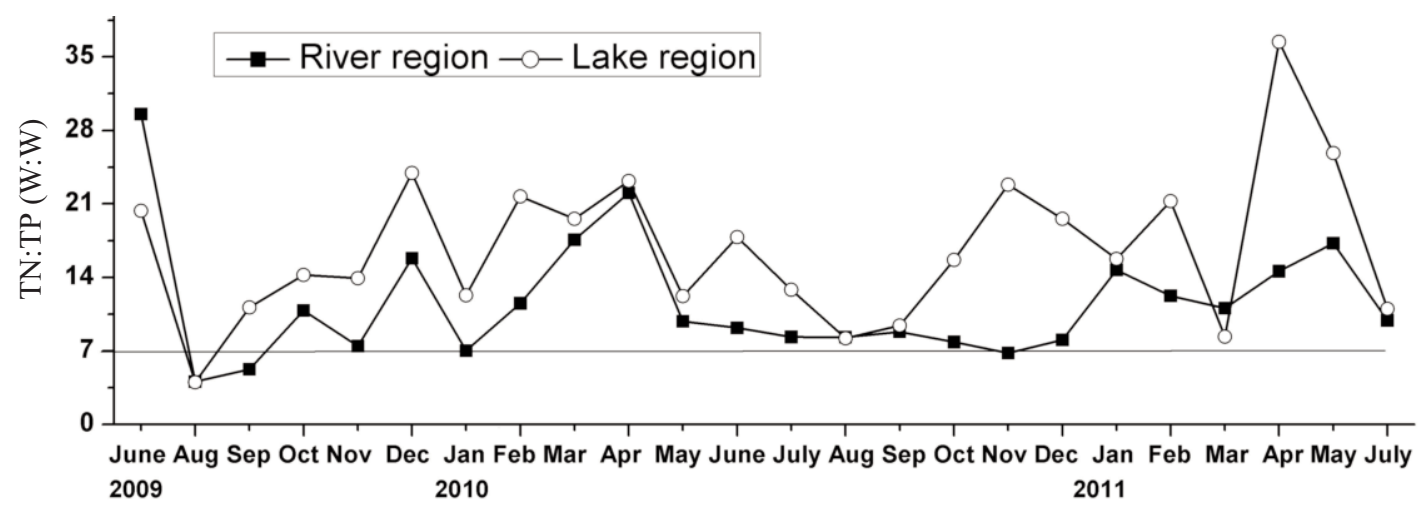

Fig. 5. TN:TP ratio in the RLCS. 
slightly higher in the lake region than in the river region, ranging from 6.76 to 8.06 in the river region and from 6.65 to 8.59 in the lake region.

Phytoplankton is a primary internal source of organic matters, so the lake region always presented a peak of $\mathrm{COD}_{\mathrm{Mn}}$ when Chl.a was very high (Figs. 3 and 4). The organics in the river region were an external source of $\mathrm{COD}_{\mathrm{Mn}}$ in the lake region. Therefore, except the peaks in the lake region (August 2009 and 2010; July 2011) the patterns of $\mathrm{COD}_{\mathrm{Mn}}$ were similar between the two regions (Fig. 4).

The concentration and trends of $\mathrm{TN}$ in the two regions were similar, as well as $\mathrm{NH}_{3}-\mathrm{N}$ and $\mathrm{NO}_{3}^{-}-\mathrm{N}$ (Fig. 4). The average concentration of $\mathrm{TN}, \mathrm{NH}_{3}-\mathrm{N}$, and $\mathrm{NO}_{3}^{-}-\mathrm{N}$ in the studied area were 4.74, 2.35, and $1.16 \mathrm{mg} / \mathrm{L}$. Both TN and $\mathrm{NH}_{3}-\mathrm{N}$ reached their peaks in winter, valleys in summer. Similarity phenomenon was observed in other RLCSs [24] and lakes [14], which may be attributed to the high efficiency of denitrification in high-temp seasons. But TN always reached its peaks two months earlier than that of $\mathrm{NH}_{3}-\mathrm{N}$. These results suggested that organic nitrogen transformed into $\mathrm{NH}_{3}-\mathrm{N}$ during this period. In addition to $\mathrm{NH}_{3}-\mathrm{N}, \mathrm{NO}_{3}^{-}-\mathrm{N}$ is another important component of $\mathrm{TN}$, so some of its peaks appeared at the same time as TN.

$\mathrm{TN}$ :TP ratio by weight ranged from 4 to 29 in the river region with a mean value of 12 (Fig. 5). However, in the lake region it ranged from 4 to 36 and with a mean value of 17. There was no significant difference of $\mathrm{TN}$ content between the two regions (Fig. 4). Therefore, the relatively high mean value of TN:TP ratio in the lake region was attributed to the decrease of average TP content in it. Smith [25] concluded that blue-green algae tended to be abundant when TN:TP ratio was less than 29 by weight. Therefore, the low TN:TP ratio may be an important reason for water bloom in the studied area. What is more, in high-temp seasons TN:TP ratios were extremely low (close to Redfield ratio $7: 1$ by weight) in the two regions. This was because of the significant decline of TN in water (Fig. 3). This result supported Xu's [26] and Paerl's [27] conclusions that nitrogen was the limiting factor in high-temp seasons (summer and fall) in Taihu.

\section{Spatial Variations of Interaction among Variables}

\section{Interaction between Chlorophyll a and Environmental Variables Based on PCA and Multivariate Regression}

Chl.a in water column is an excellent proxy for phytoplankton biomass, as well as eutrophication state. As causes or results of eutrophication, environmental variables more or less linked to phytoplankton biomass. Interaction between phytoplankton and environmental variables are important for aquatic system management. For this reason, PCA and multivariate regression were employed to explore the interaction between phytoplankton and environmental variables in the river and lake regions.

Too many inter-relating variables may confuse the understanding of their relationships. Two new uncorrelated factors generated from PCA were used to describe relationships between Chl.a and environmental variables, as well as water environment variation in the two regions (Fig. 6). Factor 1 in the two regions contributed more to the variation than Factor 2. This was especially obvious in the river region.

In the river region, the first factor (RF1) accounted for $39.22 \%$ of the total variation (Fig. 6 a). RF1 had negative relationships with $\mathrm{TN}, \mathrm{NH}_{3}-\mathrm{N}$, and $\mathrm{COD}_{\mathrm{Mn}}$, as well as DO. It also positively correlated with temp and trans. However, the second factor (RF2) in this region captured only $16.94 \%$ of the water environment variation. RF2 was related to TP, $\mathrm{NO}_{3}^{-}-\mathrm{N}$, and trans. A stepwise regression about Chl.a (dependent variable) and these two factors (dependent variables) in the river region were set as equation (2). This equation showed that a significant relationship only existed
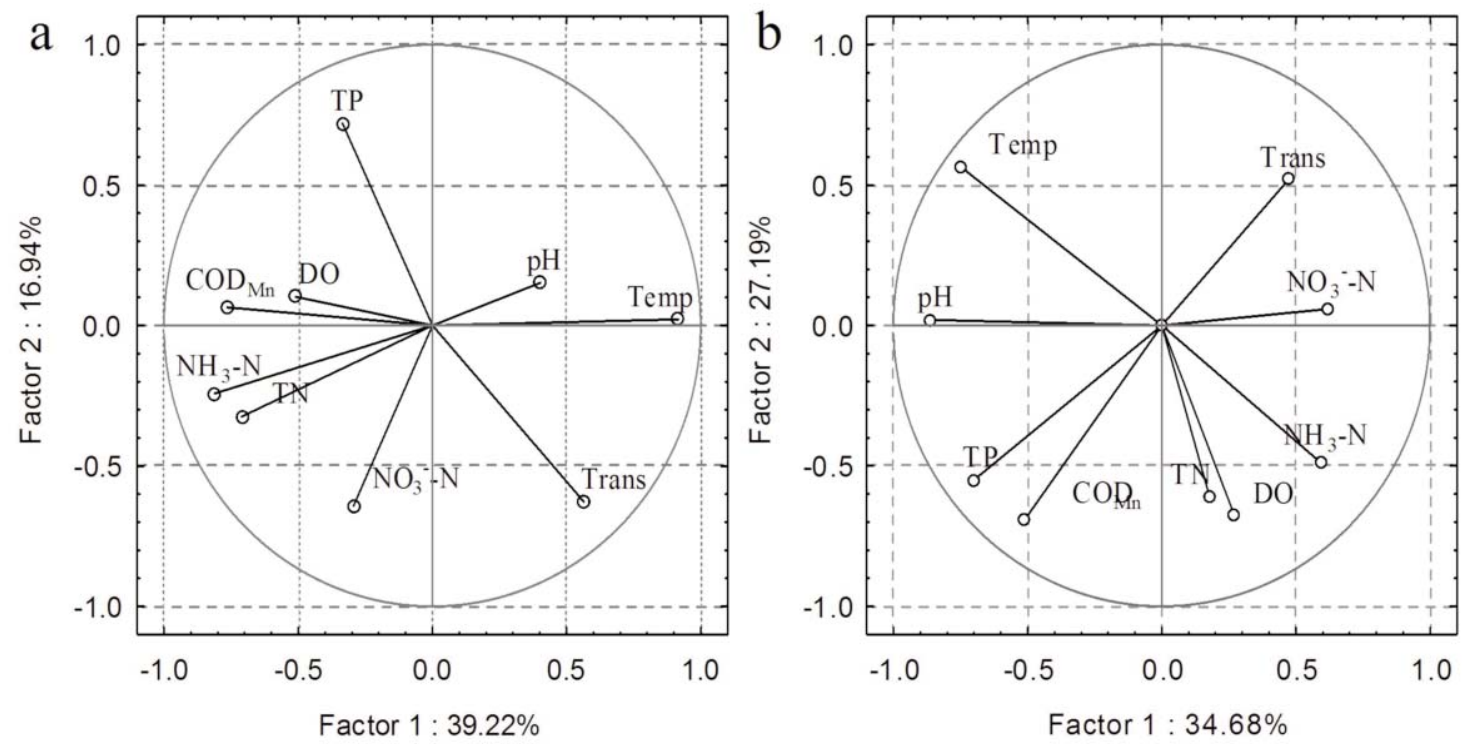

Fig. 6. Plot of factor loadings for each variable of the first two factors generated from PCA. a) the river region; b) the lake region. 
between Chl.a and RF1, indicating that Chl.a may negatively correlate with $\mathrm{TN}, \mathrm{NH}_{3}-\mathrm{N}, \mathrm{COD}_{\mathrm{Mn}}$, and $\mathrm{DO}$, and positively correlate with temp and trans. However, there were no relationships between Chl.a and TP as well as $\mathrm{NO}_{3}^{-}-\mathrm{N}$, both of wich were related to RF2. This result suggested that nutrients $(\mathrm{N}, \mathrm{P})$ were not factors limiting phytoplankton growth in the river region. In addition, physical conditions such as temp and trans may influence phytoplankton growth substantially in this region.

$$
\begin{aligned}
& \text { R-Chl. } a=5.53 R F 1+15.50 \\
& (r=0.393, p=0.002, n=66) \\
& \text { L-Chl.a }=-55.24 L F 1+34.42 \\
& (r=0.873, p<0.001, n=44)
\end{aligned}
$$

In the lake region, its first factor (LF1) accounted for $34.68 \%$ of the total variation (Fig. 6 b). It had positive correlation with $\mathrm{NH}_{3}-\mathrm{N}, \mathrm{NO}_{3}^{-}-\mathrm{N}$ as well as Trans, and negative correlation with temp, $\mathrm{pH}, \mathrm{TP}$, and $\mathrm{COD}_{\mathrm{Mn}}$. Comparing to the river region, the second factor (LF2) in the lake region was also an important contributor for total variation. It was related to almost all the monitored variables except $\mathrm{pH}$ and $\mathrm{NO}_{3}^{-}-\mathrm{N}$. The same as the river region, Chl.a in the lake region had a relationship only with the first factor. Equation (3) indicated that Chl.a in the lake region had significant relationships with all the monitored variables except TN and DO. It positively correlated with temp and $\mathrm{pH}$, as well as $\mathrm{COD}_{\mathrm{Mn}}$. Chl.a also had positive correlation with TP, which suggested that phosphorus may release from lake sediment during phytoplankton growth and sink into sediment after its death $[19,20]$.

$$
\begin{gathered}
\text { R-Chl. } a=0.826 \text { Temp }+1.056 \\
(r=0.580, P=0.006, n=66) \\
\\
\text { L-Chl.a }=143.4 \text { TP }+3.81 \text { Temp } \\
+7.467 C O D_{M n}-127.836 \\
(r=0.882, P=0.027, n=44)
\end{gathered}
$$

Using Chl.a (dependent variable) and all of the monitored variables (dependent variables), stepwise multiple regressions set up equation (4) for the river region and equation (5) for the lake region. Temp was a factor that adjusted the content of Chl.a in both regions. In addition to temp, TP and $\mathrm{COD}_{\mathrm{Mn}}$ were related to Chl.a in the lake region. What is more, TP was the first variable entered into the regression formula for this region. All these results remain consistent with the results of PCA and multivariate regression.

\section{Quantitative Correlations among Variables}

In this section, correlate analyses were used to get quantitative information about interaction among all the monitored variables (Table 1). What is more, these correlations were compared between the river region and the lake region.

Temp is an important indicator of seasonal change. It is also an important factor impacting biological, chemical, and physical process $[3,28]$. Chl.a had significant positive correlation with Temp in both regions (Table 1). Temp had negative correlations with $\mathrm{TN}, \mathrm{NH}_{3}-\mathrm{N}$, and $\mathrm{NO}_{3}^{-}-\mathrm{N}$ in both regions (Table 1). This result suggested that temp was an important determinant of phytoplankton growth and nitrogen patterns in both regions. Phytoplankton growth in hightemp seasons may cause decrease of trans. However, removal of some water pollutants in high-temp seasons may lead to a substantial increase of trans. As the data show in Fig. 3, the phytoplankton growth in the river region was weak compared with the lake region during high-temp seasons. This was why there was a negative relationship between Temp and $\mathrm{COD}_{\mathrm{Mn}}(\mathrm{r}=-0.421, \mathrm{p}<0.01)$, but a positive relationship between temp and trans $(r=0.585$, $p<0.01)$ in the river region, which were not found in the lake region. What is more, there was positive correlation between $\mathrm{TN}$ and $\mathrm{COD}_{\mathrm{Mn}}(\mathrm{r}=0.496, \mathrm{p}<0.01)$ in the river region, which suggested that $\mathrm{TN}$ and $\mathrm{COD}_{\mathrm{Mn}}$ may have some common carriers. In the lake region, only when the temp is over $20^{\circ} \mathrm{C}$ were there significant positive relationships between temp and TP $(r=0.749, p<0.01)$, as well as $\mathrm{COD}_{\mathrm{Mn}}(\mathrm{r}=0.612, \mathrm{p}<0.01)$, and a negative relationship between temp and trans $(\mathrm{r}=-0.657, \mathrm{p}<0.01)$.

Chl.a was positively correlated with TP $(\mathrm{r}=0.629$, $\mathrm{p}<0.01)$ and $\operatorname{COD}_{\mathrm{Mn}}(\mathrm{r}=0.559, \mathrm{p}<0.01)$ in the lake region. These three variables (Chl.a, TP, and $\mathrm{COD}_{\mathrm{Mn}}$ ) were negatively correlated with Trans (Table 1). These results suggested that TP, $\mathrm{COD}_{\mathrm{Mn}}$, and Chl.a had a common source, like phytoplankton, influencing the trans in the lake region. This was quite different in the river region, where only negative correlation between TP and trans as well as a positive relationship between Chl.a and trans, were found.

Temp is a key factor that controls the broken time of phytoplankton blooms in a lake. When Temp increased, both the primary productivity (indicated by Chl.a) and decomposition of pollutants were strengthened significantly in the lake region. But the increase of the primary productivity in the river region was weak when compared to the lake region. Decomposition of pollutants would deplete the amount of DO [29]. Therefore, DO, $\mathrm{COD}_{\mathrm{Mn}}, \mathrm{TN}, \mathrm{NH}_{3}$ $\mathrm{N}$, and $\mathrm{NO}_{3}^{-}-\mathrm{N}$ had significantly negative relationships with temp. As a result, the trans increased in the river region and had a significantly positive relationship with the temp. Different from $\mathrm{N}$, which would be removed from aquatic system as nitrogen gas by denitrification [30], phosphorus remained in the system and cannot be removed through the decomposition process. In contrast to the river region, in the lake region phytoplankton blooms resulted in pulse rise of organic matter and phosphorous and seriously low trans. Twofold processes working simultaneously, including increased degradation of organic matter and increased primary productivity, made the response to temp change more complex in the lake region. Lake sediment played a key role in these processes in the lake system. This may be a source of nutrients such as phosphorous [3], especially in high-temp seasons. 


\section{Comparison with other River-Lake Connecting System (RLCS)}

Some studies that simultaneously reported water quality in inflowing rivers and connecting lakes presented results similar to our investigation. Chen [31] reported that Chl.a was positively correlated with TP in Weishan Lake, but negatively in its inflowing river. This result suggested that phosphorus was not the limiting factor of phytoplankton in the river. It was the same as the river region in Taige Canal-Taihu Lake. De Emiliani [32] reported an RLCS that had water environment characteristics like Taige Canal-Taihu Lake. Both of the two RLCSs had relatively low trans and phytoplankton biomass, but high water velocity in the river region when compared with its lake region. However, in one RLCS of Qiandao lake, Chl.a and tran were negatively correlated in both river and lake water [33]. It is different from Taige Canal-Taihu Lake in which trans was one of the limiting factors in the river region and trans was positively correlated with Chl.a. These studies showed that the water quality and interaction between Chl.a and other water parameters in RLCSs are different from each other. It is important to understand the key factors that limit the growth of phytoplankton in an RLCS. Many studies indicated that besides nutrient concentration, hydrological conditions such as water depth, flow velocity, and light availability in an RLCS can also play a key role in patterns of Chl.a $[32,34]$. This point was also presented in Taige Canal-Taihu Lake, in which the flow velocity and light availability may limit phytoplankton growth in the river region. Therefore, we proposed that hydrological conditions should be paid much more attention in the future studies of water environment characteristics in RLCSs.

\section{Suggestions for Lake Eutrophication Control}

RLCS was a collection and distribution center for the pollutants. Centralized pollutants from the lake basin enter into the RLCS, where a small part of them decompose or sink into the sediment in the lake region of RLCS. However, a major part of pollutants can rush into the open lake and disperse to various places. As a result, the majority of the pollutants from the lake basin remain in the open lake region, which would depredate the lake system. High content of pollutants entered into a lake through RLCSs. Therefore, RLCS may play a key role in pollution control and lake restoration because of its geographic position and ecological significance. Intercepting pollutants at RLCSs of a lake is an excellent strategy. In Gehu lake-Taige Canal RLCS, engineering technologies including pre-reservoir technology and ecological interception technology were used to intercept pollutants [4]. Significant improvement of water quality was achieved in the demonstration project [4].

The river region in the studied area centralized pollutants from the Taige Canal and Caoqiao River, which were two main pollution sources to the upstream portion of Taihu Lake [4]. The studied RLCS should be a protection barrier guaranteeing clean water resources for upstream Taihu Lake. Based on the characteristics of the studied RLCS, enhancing its purification capacity and controlling the nutrient loadings (external and internal) should be considered to restore its structure and function. Regarding nutrient reduction, our study suggests that control of nitrogen input is crucial for eutrophication management, because our study showed that in the lake region phytoplankton growth was limited by nitrogen during hightemp seasons. Internal phosphorus loading should also be paid much attention, because it may release from sediment and support phytoplankton growth during high-temp seasons.

\section{Conclusions}

RLCS was important to the management of lake eutrophication for its special geographical position and ecological environment. Intercepting pollutants at RLCSs of a lake is an excellent strategy for eutrophication control. Since the Taige Canal and Caoqiao River were two main pollution sources to the upstream portion of Taihu Lake, intercepting pollutants at the Taige Canal-Taihu lake RLCS would be an effective strategy of guaranteeing clean water for Taihu Lake's upstream.

The Taige Canal-Taihu lake RLCS could be statistically divided into a river region and a lake region. Chl.a in the river region is lower than that in the lake region. Compared with the river region, concentrations of $\mathrm{TP}$, and $\mathrm{NH}_{3}-\mathrm{N}$ in the lake region decreased by $33.8 \%$ and $16.0 \%$, respectively. Trans increased by $35.2 \%$ and DO content decreased by $15.0 \%$. There were no obvious changes in terms of average content for other variables.

TP, Chl.a, and trans were the primary determinants of the spatial variations between the river region and the lake region. In the river region, temp and trans were the primary environmental factors limiting phytoplankton growth. However, in the lake region phytoplankton growth was limited by both nitrogen (in high-temp seasons) and phosphorus (over the whole year). Our study suggested that reduction of nitrogen input and control of internal phosphorous loading was important for the management of eutrophication in the studied RLCS.

\section{Acknowledgements}

This work was supported by funding from the State Key Laboratory of Freshwater Ecology and Biotechnology (No. 2014FB09) and the Fundamental Research Funds for the Central Universities (2014NZYQN18), water environment special item (2012ZX07101-007). We also give our thanks to anonymous reviewers for providing useful comments on the paper. 


\section{References}

1. CONLEY D.J., PAERL H.W., HOWARTH R.W., BOESCH D.F., SEITZINGER S.P., HAVENS K.E., LANCELOT C., LIKENS G.E. Controlling eutrophication: nitrogen and phosphorus. Science. 323, (5917), 1014, 2009.

2. CARPENTER S.R., CARACO N.F., CORRELL D.L., HOWARTH R.W., SHARPLEY A.N., SMITH V.H. Nonpoint pollution of surface waters with phosphorus and nitrogen. Ecol Appl. 8, (3), 559, 1998.

3. SNDERGAARD M., JENSEN J.P., JEPPESEN E. Role of sediment and internal loading of phosphorus in shallow lakes. Hydrobiologia. 506, (1), 135, 2003.

4. ZHANG Y.M., ZHANG Y.C., GAO Y.X., ZHANG H.H., CAO J.Y., CAI J.B., KONG X.J. Water pollution control technology and strategy for river-lake systems: a case study in Gehu Lake and Taige Canal. Ecotoxicology. 20, (5), 1154, 2011.

5. BAIN M.B., CANGELOSI A., EDER T.A. Monitoring microbes in the Great Lakes. Environ Monit Assess. 182, (14), 431, 2011.

6. RICHARDSON C.J., FLANAGAN N.E., HO M., PAHL J.W. Integrated stream and wetland restoration: A watershed approach to improved water quality on the landscape. Ecol Eng. 37, (1), 25, 2011.

7. JIA Y., YANG Z., SU W., JOHNSON D., KONG F. Controlling of cyanobacteria bloom during bottleneck stages of algal cycling in shallow Lake Taihu (China). J Freshwater Ecol. 29, (1), 129, 2013.

8. HUI T., XIE P., GUO L., CHU Z., LIU M. Phytoplankton dynamics and their equilibrium phases in the Yanghe Reservoir, China. J Freshwater Ecol. 29, (1), 1, 2013.

9. ESSINGTON T.E., CARPENTER S.R. Nutrient Cycling in Lakes and Streams: Insights from a Comparative Analysis. Ecosystems. 3, (2), 131, 2000.

10. QIN B.Q., ZHU G.W., GAO G., ZHANG Y.L., LI W., PAERL H.W., CARMICHAEL W.W. Carmichael, A Drinking Water Crisis in Lake Taihu, China: Linkage to Climatic Variability and Lake Management. Environ Manage. 45, (1), 105, 2010.

11. ADMINISTRATION S.E.P. Environmental Quality Standards for Surface Water (GB3838-2002): published at 28 April 2002 and implemented at 1 June 2002.

12. ZHENG Y., WANG X.J., JIANG Y.C., ZHOU X.W. Analysis on water quality of rivers around Tai Lake and estimation of total pollutant load into Tai Lake. Geography and Territorial Research. 17, (1), 40, 2001.

13. ADMINISTRATION S.E.P. Water and wastewater monitoring and analysis method, fourth ed. Beijing: China: Environmental Science Press. 2002.

14. JING L.D., LIU J.T., AO H.Y., WANG H.G. Nutrients distibution and water quality of mesotrophic Dongqian Lake: a study focused on phytoplankton, sediment and phosphorus. Fresen Environ Bull. 20, (11A), 3014, 2011.

15. AHANEKU I.E., SADIQ B.O. Assessment of Heavy Metals in Nigerian Agricultural Soils. Pol J Environ Stud. 23, (4), $1091,2014$.

16. KAISERLI A., VOUTSA D., SAMARA C. Phosphorus fractionation in lake sediments - Lakes Volvi and Koronia, N. Greece. Chemosphere. 46, (8), 1147, 2002.

17. WANG X.L., LU Y.L., HE G.Z., HAN J.Y., WANG T.Y. Multivariate analysis of interactions between phytoplankton biomass and environmental variables in Taihu lake, China. Environ Monit Assess. 133, (1-3), 243, 2007.
18. NGUYEN H.V., SHIN J.K., HUR J. Multivariate analysis for spatial distribution of dissolved organic matters in a large river-type dam reservoir. Environ Monit Assess. 183, (1-4), 425, 2011.

19. XIE L., XIE P., LI S., TANG H., LIU H. The low TN: TP ratio, a cause or a result of Microcystis blooms? Water Res. 37, (9), 2073, 2003.

20. XIE L., XIE P., TANG H. Enhancement of dissolved phosphorus release from sediment to lake water by Microcystis blooms--an enclosure experiment in a hyper-eutrophic, subtropical Chinese lake. Environ Pollut. 122, (3), 391, 2003.

21. DUAN H., MA R., XU X., KONG F., ZHANG S., KONG W., HAO J., SHANG L. Two-decade reconstruction of algal blooms in China's Lake Taihu. Environ sci technol. 43, (10), 3522, 2009.

22. LI F., ZHANG H., ZHU Y., XIAO Y., CHEN L. Effect of flow velocity on phytoplankton biomass and composition in a freshwater lake. Sci Total Environ. 447, 64, 2013.

23. SONG X., LIU Z., YANG G., CHEN Y. Effects of resuspension and eutrophication level on summer phytoplankton dynamics in two hypertrophic areas of Lake Taihu, China. Aquat Ecol. 44, (1), 41, 2010.

24. KNEIS D., KNOESCHE R., BRONSTERT A. Analysis and simulation of nutrient retention and management for a lowland river-lake system. Hydrol Earth Syst Sc. 10, (4), 575, 2006.

25. SMITH V.H. Low nitrogen to phosphorus ratios favor dominance by blue-green algae in lake phytoplankton. Science. 221, (4611), 669, 1983.

26. XU H., PAERL H.W., QIN B., ZHU G., GAO G. Nitrogen and phosphorus inputs control phytoplankton growth in eutrophic Lake Taihu, China. Limnol Oceanogr. 55, (1), 420, 2010.

27. PAERL H.W., XU H., MCCARTHY M.J., ZHU G., QIN B., LI Y., GARDNER W.S. Controlling harmful cyanobacterial blooms in a hyper-eutrophic lake (Lake Taihu, China): the need for a dual nutrient $(\mathrm{N} \& \mathrm{P})$ management strategy. Water Res. 45, (5), 1973, 2011

28. BOSTR M B., ANDERSEN J.M., FLEISCHER S., JANSSON M. Exchange of phosphorus across the sediment-water interface. Hydrobiologia. 170, (1), 229, 1988.

29. DU X.L., XU Z.X., WANG S. Enhanced Removal of Organic Matter and Ammonia Nitrogen in a One-Stage Vertical Flow Constructed Wetland System. Environ Prog Sustain. 29, (1), 60, 2010.

30. PI A-OCHOA E., ÁlVAREZ-COBELAS M. Denitrification in aquatic environments: a cross-system analysis. Biogeochemistry. 81, (1), 111, 2006.

31. CHEN J., WANG C., JIANG W. The Research of Chlorophyll $a$ Contents and Primary Production in the Weishan Lake in Spring 2010. Chinese Agricultural Science Bulletin. 27, (23), 265, 2011.

32. DE EMILIANI M.O.G. Effects of water level fluctuations on phytoplankton in a river-floodplain lake system (Paraná River, Argentina). Hydrobiologia. 357, (1-3), 1, 1997.

33. WANG F., LUE H., CHEN Y., TIAN G., YU Z. Analysis of the spatial and temporal changes in chlorophyll- $a$ concentration in Qiandao Lake and its impact factors. Journal of Zhejiang University(Agriculture and Life Sciences). 30, (1), 22, 2004.

34. BAHNWART M., H BENER T., SCHUBERT H. Downstream changes in phytoplankton composition and biomass in a lowland river-lake system (Warnow River, Germany). Hydrobiologia. 391, (1-3), 99, 1998. 
